\title{
RE-CONNECTING ONESELF TO THE WORLD OF PEERS VIA THE CONTEMPLATION OF AN ARTWORK
}

\author{
Laurence Bertron-Gatier, \& Célia Vaz-Cerniglia \\ The Catholic University of Lyon (France)
}

\begin{abstract}
Some teenagers have no more confidence to exchange with each other and with adults through words. Not desire can enroll in the relation because it has become suspicious; or even defying due to psychic and emotional pain. This suffering is trying to be hidden because is even hardly accessible, intelligible to their conscience. They are in a vulnerable period and some of them are closing them in on themselves.

These teenagers, who lock themselves certainly to looking away, might catch their gaze in a pictorial scene. This scene included in a frame containing an art production which is given to see, that invites contemplation without risk of intrusion. It would provide, without doubt, a space to rush, or even to take refuge there. It would be a landscape that would allow these teenagers to flee in a space deeper and deeper, echoing the depth of their physical and emotional proven. Maybe in this place at once more and less distanced, these young teens might find a correct distance, more adjusted; they can develop more openness and further more deploy their senses.

By sense, we mean both the sensory modalities, the sense of direction and meaning.

Take the time to let yourself be surprised by an artist's painting which has been chosen, be able to choose it to contemplate in his own way, in a small room would promote an authentic encounter between the teenager and the artist via the painting. his intertwining of spaces and double projections and transfers build an environment sufficiently containing. It invites to daydreaming, poetry and a great sense of wonder offsetting an environment of the depression and destruction.

This moment of intimate and authentic meeting would promote the deployment of self-confidence and in each other. Effectively, the young teenager feels intimately known by this other who expresses through his artwork. Thus, the identification process is initiated.

Thus, the aim of this oral paper is to emphasize the importance of a device such as the Artothèque to accompany early adolescents who are in down development and have difficulty in communication and relationship with the other.

Some clinical cases will be presented to illustrate the authentic encounter between the young and the artwork at one point and thereafter.
\end{abstract}

Keywords: Artothèque, artwork, wonderment, the encounter with the other, senses.

\section{Problematic}

How can we render the meeting between an adolescent in a precarious relational situation with the work of an artist in an authentic and reciprocal manner? Convoked in new feelings, how can they transform their defensive acts into symbolised objects? We are going to attempt to capture the process of this psychic task, with a possible challenge concerning the restauration of the narcissism and a "re-connection" to the world.

\section{Hypothesis}

The contemplation of an artwork, a veritable landscape, allows certain adolescents in crisis points to find refuge. Without a fear of being seen or judged in this more isolated and deep space, they can preserve their sense of privacy, which also echoes the depth of their corporal and emotional feelings. 


\section{Framework}

Public: adolescents in relational crises concerning the familial, social and scholarly domains, in a space named the "Resource area" (day centres, childhood protection, and legal youth protection).

Art Library: Contemplating an ensemble of artworks in a public space and then choosing one that the adolescent will bring and present in the Resource Area.

\section{Results}

Certain adolescents are emotionally touched by the contemplation of an artwork in situ. The moving of the chosen artwork, when the adolescent actually puts the piece in his hands in front of everyone, is accompanied by a psychic movement that operates in reciprocity (the convergence between the psychic world of the artist and that of the adolescent), (Guillaumin, 1998).

A psychic and physical movement is initiated following a sudden emotional experience. Certain people begin to feel once again. Working from the artwork that seems to protect the adolescent almost as if being a new containing envelope, they begin to experiment more and more with their fixed and deeply buried experiences.

Their feelings are anchored in either the intention of the artist (painting by V. Velickovic, "Experience", 1974), or the artist themselves (H. Michaux and painting, no title, 1949), and sometimes in both. For the first, the teenager can, via the painting makes himself the experience of an intrusion like a dissection. For the second, he can feel and understand how cannabis enables him to hide and put out his depression.

\section{Discussion}

If there is a convergence between the adolescent and the artwork, this would invoke a psychic space that liberates itself from real time while driving a subjective appropriation of experiences and feelings, which are sometimes traumatic for certain people. This thereby participates in narcissistic restauration through the introjection of the beauty or strangeness perceived within the process of identification to an artist or his artwork. The adolescents are eventually able to find themselves, in part, in the artist's sublimated reality. This encounter offers the opportunity to distance oneself from the destructive movements (Winnicott, 1994) that animated them until that point, in order to open and re-connect themselves to a shared sensitivity. These meetings, surprising due to their unexpected nature, have a strong re-narcissising effect for certain people, because their sensitivity is then socially legitimised in their eyes (Chouvier, 2002).

\section{Conclusion}

The contemplation of an artwork that has captured their attention, an artwork that is both a pictorial representation of another's psychic space and as well as an opportune space for their own projections, these adolescents are then enabled to find the right distance between what the artwork invokes (intentionality of the artist) and what they themselves perceive and feel. The aesthetic implies that a process of transformation is at work, rather than displacement, concerning that which was until that point inexpressible. It initiates an inter and intra psychic movement within the adolescent that is ideal for the task of symbolization.

\section{References}

Chouvier, B. (2002). Les processus psychiques de la médiation. Paris: Dunod.

Guillaumin, J. (1998). Le jugement esthétique, un instrument logique étrange entre l'intime et l'universel. In B. Chouvier \& al. (Eds.), Symbolisation et processus de création: Sens de l'intime et travail de l'universel dans l'art et la psychanalyse (Inconscient et culture) (pp. 35-56). Paris: Dunod.

Winnicott, D.W., (1994). La tendance antisociale. In D.W. Winicott (Ed.), déprivation et délinquance (pp. 145-158). Paris: Payot (article original publié en 1956) 